\title{
PENINGKATAN KETRAMPILAN KOMUNIKASI DENGAN PEMBUATAN NAWALA UNTUK TENAGA PENDIDIKAN DI SIDOARJO
}

\author{
Fanny Lesmana $^{1 *}$, Asthararianty ${ }^{2}$, Monica Rusdianto ${ }^{3}$ \\ ${ }_{123}$ Program Studi Ilmu Komunikasi, Fakultas Ilmu Komunikasi \\ Universitas Kristen Petra Surabaya, Jl. Siwalankerto 121-131, Surabaya 60236 \\ *Penulis korespondensi; email: flesmana@petra.ac.id
}

\begin{abstract}
Abstrak: Tenaga pendidik membutuhkan sebuah ketrampilan untuk menyampaikan informasi perihal aktivitas di sekolah kepada publik internal maupun publik eksternal, tidak hanya secara lisan, melainkan secara tertulis. Karenanya, diperlukan sebuah ketrampilan komunikasi dalam upaya penyampaian informasi secara tertulis. Salah satu peningkatan ketrampilan komunikasi ditunjukkan melalui pembuatan Nawala sebagai salah satu media informasi yang diperlukan oleh sebuah institusi pendidikan. Dengan demikian, setiap sekolah dapat menyampaikan informasi yang diperlukan oleh khalayak. Pelatihan dan pendampingan ini diadakan bagi tenaga pendidik dari sekolah-sekolah di Kota Sidoarjo, Jawa Timur agar mereka terampil dalam membuat Nawala. Jumlah peserta pelatihan adalah 8 (delapan) orang. Pelatihan dibagi menjadi tiga sesi, yakni memahami nawala sebagai bagian dari public relations, berlatih menulis berita sederhana, kemudian dilanjutkan dengan berlatih membuat desain sederhana. Pelatihan ini dilakukan selama $10 \mathrm{kali}$, mulai dari membagikan materi perihal penulisan hingga membuat desain Nawala yang sederhana. Selanjutnya, penulis dan tim memberikan pendampingan dalam praktik pembuatan Nawala yang langsung dapat dipergunakan oleh setiap peserta. Pada akhir pelatihan dan pendampingan ini, peserta telah membuat Nawala karya sendiri. Hasil karya Nawala tersebut dicetak sehingga dapat dibagikan pada masingmasing publiknya sebagai media informasi bagi tiap institusi.
\end{abstract}

Kata kunci: Pelatihan, komunikasi, penulisan, desain, nawala

\begin{abstract}
Educators need skills to convey information about activities at school to the internal and external public, not only verbally, but also in writing. Therefore, we need communication skills in an effort to convey information in writing. One of the improvements in communication skills is shown through the making of newsletter as one of the information media needed by an educational institution. Thus, each school can convey the information needed by the public. This training and mentoring is held for educators in Sidoarjo City, East Java so that they are skilled in making newsletter. The number of training participants is 8 (eight) people. The training is divided into three sessions. First, understanding newsletters as part of public relations, practicing simple news writing, then continuing with practicing making simple designs. This training was conducted for 10 times, starting from distributing material regarding writing to creating a simple newsletter design. Furthermore, the authors and the team provide assistance in the practice of making newsletter which can be used directly by each participant. At the end of this training and mentoring, the participants have made their own newsletter. The newsletter is printed so that it can be shared with each public as a medium of information for each institution.
\end{abstract}

Keywords: Training, communication, writing, design, newsletters.

\section{PENDAHULUAN}

Sekolah sebagai instansi pendidikan juga perlu untuk menginformasikan aktivitas yang dilakukan, baik oleh para siswa maupun para tenaga pendidik kepada publik secara luas ataupun publik internal, seperti halnya orang tua siswa maupun masyarakat di sekitar lingkungan sekolah.
Informasi perihal aktivitas dalam sekolah ini menjadi penting karena selain dapat dipergunakan sebagai sarana untuk membagikan informasi terbaru, juga dapat menjadi sarana untuk meningkatkan kesadaran masyarakat perihal pentingnya pendidikan formal, serta dapat menjadi media untuk menjaga reputasi sebuah instansi, yang dalam hal ini adalah sekolah. 
Tenaga pendidik adalah salah satu jembatan penghubung antara sekolah dengan orang tua siswa-siswi. Tenaga pendidik memerlukan ketrampilan berkomunikasi dalam hal penyampaian informasi-informasi tersebut. Salah satunya adalah dengan ketrampilan berkomunikasi melalui media Nawala, yang merupakan media yang mampu dipakai untuk penyampaian informasi-informasi yang butuh disebarkan oleh sekolah kepada khalayak.

Tenaga pendidik bukan hanya dipenuhi dengan hal-hal pokok seperti pemahaman terhadap materi namun juga perlu diberikan pemahaman mengenai ketrampilan berkomunikasi melalui media Nawala ini. Pelatihan dan pendampingan ini diadakan bagi tenaga pendidik dari sekolah-sekolah di Kota Sidoarjo, Jawa Timur agar mereka terampil dalam membuat Nawala. Jumlah peserta pelatihan adalah 8 (delapan) orang perwakilan tenaga pendidik yang berasal dari sekolah SMP Negeri 5 Sidoarjo, SD Santa Maria Sidoarjo, BimBel TEKNOS Sidoarjo, KB/ TK Santa Maria Sidoarjo, SD Sidoklumpuk Sidoarjo, SMP Santa Maria II Sidoarjo.

Morissan $(2014,88)$ menegaskan bahwa lembaga PR di sekolah bertugas untuk membantu terciptanya komunikasi yang baik antara guru dengan orang tua dan murid. Tugas lainnya adalah membina hubungan dengan dewan sekolah, lembaga pemerintah, juga dengan media massa. Sementara itu, dalam buku Manajemen Humas pada Lembaga Pendidikan (Bahri, 2020) disebutkan ada 6 (enam) tugas PR dalam lembaga pendidikan yang secara umum dapat disimpulkan adalah mempersiapkan pimpinan sekolah dalam mempersiapkan konten informasi yang akan disebarluaskan pada masyarakat maupun pada pihakpihak lainnya.

Karena itu, informasi yang disampaikan tidak hanya bersifat non formal atau melalui pesan lisan belaka. Sebab pesan lisan hanya dapat diterima oleh sebagian orang saja. Selain itu, informasi lain yang disampaikan melalui kotak pesan baik secara personal maupun kelompok, belum tentu dapat menjangkau masyarakat secara luas. Sebab tidak semua orang tergabung di dalam kelompok kotak pesan. Untuk itu dibutuhkan sebuah media yang dapat memuat perihal informasi berupa aktivitas siswa dan guru, maupun informasi penghargaan yang diterima sekolah, dan sebagainya.

Nawala (newsletter) merupakan salah satu media yang dipergunakan oleh sebuah instansi atau institusi dalam mempublikasikan diri kepada khalayak. Dalam buku Public Relations Writing, Sopian $(2016,132)$ mencantumkan beberapa definisi perihal Nawala. Salah satu di antaranya dikutip dari Ronald D. Smith (2003) yang menyatakan nawala merupakan alat $\mathrm{PR}$ yang penting untuk menjalin relasi dengan publik. Sedangkan menurut Pamela Brooks (2002), nawala adalah seperangkat informasi yang keberadaannya membuat pembacanya menjadi bagian dari komunitas.

Berkenaan dengan hal itu, maka sekolah sebagai salah satu bentuk institusi juga perlu untuk membuat nawala sehingga dapat menjalin relasi dengan publik, baik itu orang tua siswa maupun masyarakat luas. Informasi yang disampaikan oleh pihak sekolah kepada publik dapat dilakukan melalui nawala, yang meliputi informasi kegiatan di sekolah maupun di luar sekolah, penghargaan yang diterima oleh siswa maupun guru, serta pengumuman baik dari sekolah maupun dari institusi terkait yang ada hubungannya dengan situasi proses pendidikan dan pengajaran di sekolah.

Karenanya, tujuan pengabdian masyarakat ini adalah untuk memperlengkapi para guru dalam hal pemahaman akan pembentukan citra institusi baik secara internal maupun eksternak. Selain itu, pengabdian masyarakat ini bertujuan memberikan ketrampilan pada para guru dalam hal pembuatan nawala.

Sebagai luaran dari pengabdian masyarakat ini adalah nawala (newsletter) yang dipublikasikan secara regular di kalangan internal, yakni sekolah. Untuk edisi pertama, tim penulis turut mencetak nawala tersebut sehingga dapat dibagikan pada publik.

Manfaat pengabdian masyarakat ini adalah untuk memberikan pengetahuan dasar perihal kinerja Public Relations, khususnya di lembaga pendidikan, juga memberikan ketrampilan sederhana dalam pembuatan nawala, baik dalam hal ketrampilan menulis maupun ketrampilan mendesain.

Kajian Pustaka yang dipergunakan dalam pengabdian masyarakat ini adalah Nawala dan Public Relations, proses dan teknik menulis berita serta teknik tata letak untuk nawala.

Media massa memiliki kemampuan dalam hal mempublikasikan sebuah peristiwa kepada khalayak (publik). Namun tidak semua aktivitas atau kegiatan dapat dipublikasikan oleh media massa. Salah satu kendalanya adalah jumlah jurnalis yang terbatas maupun jumlah halaman yang terbatas. Kendala lain yang bisa dibantu oleh tenaga PR adalah memberikan informasi pada media massa perihal aktivitas yang sedang dilakukan oleh institusinya misalnya saja melalui press release maupun press conference. Selain itu, tenaga PR juga bisa menerbitkan nawala sebagai bahan bagi pemberitaan di media massa (Kriyantono, 2014, 322). Guru, sebagai tenaga pendidik, juga bisa berfungsi sebagai tenaga PR di dalam menjalankan kinerjanya dalam sebuah institusi. 
Ali (2017, 72) dalam bukunya Marketing Public Relations Diantara Penjualan dan Pencitraan menjelaskan bahwa salah satu keahlian yang wajib dimiliki oleh tenaga PR yang profesional adalah keahlian menulis, termasuk di antaranya adalah mengelola nawala. Karenanya, tidak dapat dihindari lagi, keahlian menulis yang dimaksud di sini adalah gaya penulisan yang berbentuk berita.

Proses penulisan berita tidak dapat terlepas dari ketrampilan yang dimiliki oleh seorang tenaga PR. Meski demikian, siapa pun dapat memiliki ketrampilan menulis berita asalkan mau berlatih. Karenanya dalam pengabdian masyarakat ini, tim penulis juga mengajak peserta untuk melatih diri dalam ketrampilan menulis berita. Salah satu hal yang perlu dipertimbangkan dalam penulisan sebuah berita adalah adanya nilai berita (news value). Menurut pandangan Supadiyanto (2020, 121-122), beberapa nilai berita dalam konteks modern adalah aktualitas, kedekatan, keterkenalan, dampak, human interest, konflik, seks serta kemajuan. Dalam penulisan berita untuk nawala, teristimewa untuk institusi pendidikan, maka nilai berita yang dapat digagas adalah aktualitas, kedekatan, keterkenalan, dampak, human interest serta kemajuan.

Berita memiliki banyak definisi. Salah satunya disebutkan oleh Hikmat $(2018,148)$ yakni berita sebagai laporan tercepat dari suatu aktivitas. Hal ini sejalan dengan kehadiran nawala yang kontennya berisi informasi sebuah kegiatan atau aktivitas dari sebuah lembaga pada masyarakat secara luas. Tidak dapat dipungkiri juga berita juga menjadi sarana dokumentasi yang baik bagi sebuah institusi. Nawala tentu saja juga bisa menjadi media dokumentasi yang baik bagi sebuah institusi, termasuk bagi institusi pendidikan.

Lesmana (2017, 66) menjelaskan bahwa penulisan berita pada umumnya dilakukan dengan cara yang serupa, yakni mengumpulkan data melalui observasi dan wawancara. Karenanya, dalam pembuatan konten nawala, pengelola juga wajib untuk membuat konten melalui teknik pengumpulan data yang sama.

Selanjutnya, dalam buku yang sama, Lesmana $(2017,88)$ menunjukkan perihal struktur penulisan berita dibagi menjadi tiga, yakni lead, isi berita dan penutup. Namun sebelumnya lead, ada judul yang perlu ditampilkan dalam setiap konten yang dituliskan.

Pembuatan nawala tidak berhenti pada penulisan konten berita. Pembuatan nawala perlu diselesaikan dengan adanya desain tata letak. Menurut Rustan (2020, 10), yang dimaksud dengan tata letak (lay out) adalah penempatan elemen desain di bidang tertentu untuk menyampaikan pesan di dalamnya, agar mempengaruhi persepsi khalayak atau pembaca saat melihatnya.
Elemen desain yang dimaksud ada dua macam. Rustan $(2020,84)$ menyebutnya sebagai konstruksi dan konten. Konstruksi bersifat kerangka atau alat bantu yang tidak terlihat. Sementara konten adalah hal yang ditaruh di dalam konstruksi tersebut. Di dalam konstruksi terdiri atas margin dan grid. Keduanya merupakan alat bantu yang tidak terlihat. Sementara untuk konten, adalah elemen teks dan gambar. Keduanya, baik konstruksi maupun konten, merupakan elemen yang dibutuhkan untuk kehadiran sebuah nawala.

\section{METODE PELAKSANAAN}

Kegiatan pengabdian masyarakat ini dilaksanakan dengan 2 (dua) metode pelaksanaan. Kedua metode tersebut adalah sebagai berikut:

1) Metode ceramah dilakukan untuk menjelaskan perihal konsep Public Relations serta nawala sebagai materi penyampaian informasi, juga penjelasan materi penulisan berita dan materi teknik tata letak

2) Metode pendampingan. Metode ini dipergunakan untuk mengajak peserta turut serta mempraktikkan materi yang telah disampaikan sebelumnya. Praktik ini diperlukan agar peserta dapat secara langsung menerapkan materi yang telah diperoleh dalam ceramah. Dengan demikian, peserta tidak hanya memperoleh pengetahuan dan wawasan, melainkan juga dapat memiliki pengalaman membuat nawala.

\section{HASIL DAN PEMBAHASAN}

Dirangkum dari buku Public Relations Writing, Sopian (2016, 132) mengutip beberapa sumber yang menjelaskan bahwa tujuan dari penerbitan nawala meliputi: 1) untuk menjaga hubungan dengan publik, (2) untuk berkomunikasi secara teratur dengan publik, (3) untuk meningkatkan atau mempertahankan sikap positif publik. Proses pendampingan pembuatan nawala yang ditujukan bagi tenaga pendidik di Siodarjo ini bertujuan untuk menjaga hubungan dengan publik, baik itu publik eksternal maupun publik internal dengan cara menyampaikan informasi perihal aktivitas yang dilakukan oleh sekolah. Dengan demikian, melalui publikasi nawala yang dibuat oleh para guru, sikap positif publik dapat terus dipertahankan.

Pertemuan baik dalam pelatihan maupun pendampingan ini berlangsung selama beberapa kali di salah satu lembaga pendidikan di Sidorajo. Pemilik lembaga pendidikan ini juga merupakan saluran dalam pelaksanaan pengabdian masyarakat ini. Pelatihan dan pendampingan ini dilakukan kepada 8 orang perwakilan dari sekolah SMP Negeri 5 Sidoarjo, SD Santa Maria Sidoarjo, 
BimBel TEKNOS Sidoarjo, KB/ TK Santa Maria Sidoarjo, SD Sidoklumpuk Sidoarjo, SMP Santa Maria II Sidoarjo.

Materi pertama yang disampaikan adalah penjelasan perihal kinerja tenaga PR dan hubungannya dengan publikasi nawala. Meskipun peserta dalam pengabdian masyarakat ini bukan sepenuhnya tenaga PR, namun dirasa perlu untuk menyampaikan materi ini agar peserta semakin memahami fungsi nawala. Setelah penyampaian materi, peserta diberi kesempatan untuk bertanya dan mendiskusikan hal ini.

Materi ini perlu disampaikan agar peserta memahami pentingnya keberadaan nawala dalam sebuah institusi, khususnya lembaga pendidikan seperti sekolah. Harapannya adalah supaya publik dapat mengetahui aktivitas yang dilakukan oleh sekolah dan terus membangkitkan sikap positif dari publik terhadap sekolah sebagai institusi pendidikan. Tim penulis juga memberikan post-test pada peserta sebagai evaluasi dari pemahaman terhadap materi ini.

Materi kedua diberikan dengan pemaparan materi tentang penulisan. Materi dibagikan tim penulis pada peserta melalui slide dalam satu kali pertemuan yang diselingi dengan tanya jawab. Sebagian besar dari peserta tidak terlalu akrab dengan dunia menulis, khususnya dalam hal penulisan berita. Namun tidak ada kendala yang berarti dalam proses penyampaian materi karena peserta aktif dalam memberikan respon.

Materi kedua ini dilanjutkan dengan praktik menulis berita yang dilakukan oleh peserta. Untuk memulai proses menulis berita, peserta terlebih dahulu diminta melakukan praktik observasi maupun wawancara untuk mengumpulkan data-data yang akan ditulis sebagai berita. Observasi dan wawancara perlu dilakukan semua dalam hal penulisan berita untuk mendapatkan tulisan yang akurat. Hasil dari observasi maupun wawancara yang dilakukan peserta di sekolah masing-masing, didiskusikan dalam satu kali pertemuan karena pertemuan berikutnya akan diisi dengan persiapan penulisan berita.

Tim penulis mewajibkan peserta untuk menulis minimal 4 (empat) tulisan untuk nawala yang akan diproduksi dikarenakan nawala tersebut terdiri dari 4 (empat) halaman. Maka, untuk observasi maupun wawancara untuk tulisan berikut didiskusikan bersamaan dengan proses penulisan maupun pada saat memasukkan konten dalam kerangka desain.

Berita yang ditulis oleh peserta diperoleh dari data-data berupa observasi dan wawancara yang dilakukan oleh peserta di masing-masing instansi. Tim penulis memberikan pendampingan dalam proses satu tulisan. Selanjutnya, tulisan didiskusi- kan saat memasukkan konten berita dalam kerangka desain. Ketika peserta telah mendapatkan masukan untuk satu tulisan, maka pertemuan berikutnya diisi dengan materi ketiga.

Materi ketiga menjelaskan perihal materi tata letak (lay out). Tim penulis membagikan materi terkait tata letak untuk menghasilkan produk nawala yang utuh. Konstruksi dan konten dalam elemen desain yang dimaksud oleh Rustan adalah hal-hal yang mendukung tingkat keterbacaan dalam sebuah nawala. Pemilihan jenis huruf, gambar, kemudian grid akan memberikan pengaruh kenyamanan dalam membaca. Antara pesan, konsep dan desain yang ingin disampaikan harus mampu digambarkan oleh pemilihan jenis huruf dan gambar. Selain itu, tim penulis juga menyampaikan perihal pemilihan warna.

Pemilihan warna dan jenis huruf berpengaruh pada target pembaca dari nawala yang akan dipublikasikan. Dengan demikian, peserta dapat menentukan siapakah yang akan menjadi target pembaca dari nawala yang akan dibuat, apakah untuk siswa, untuk orang tua ataukah untuk orang tua.

Para peserta dalam kegiatan pengabdian masyarakat ini mengikuti materi dengan antusias walaupun semua peserta tidak memiliki pengalaman dengan dunia desain sebelumnya. Mereka juga tampak sangat bersemangat saat mencoba untuk melakukan praktik potong dan tempel, yaitu sebuah latihan lay out secara manual. Setelah itu mereka mencoba membuat sendiri.

Pada pertemuan terakhir, peserta menyelesaikan nawala yang dibuat dengan menggunakan laptop masing-masing. Tim penulis memberikan masukan dalam hal penulisan maupun dalam pembuatan desain tata letak. Peserta yang dianggap sudah cukup dalam hal penulisan maupun desain dibantu oleh tim penulis untuk mencetak dengan menggunakan printer yang dibawa oleh tim penulis. Sebelum pertemuan dibubarkan, peserta dan tim penulis mengambil gambar bersama sembari membawa nawala yang telah dibuat dan dicetak.

Sebagai langkah terakhir dari pengabdian masyarakat ini adalah tim penulis menggandakan hard copy dari hasil karya peserta untuk dibagikan pada publik. Setiap peserta memperoleh 25 eksemplar hard copy dari nawala yang dihasilkan. Seharusnya ada 11 peserta dalam pelatihan ini, namun karena beberapa hal maka hanya ada enam peserta yang mengumpulkan karya nawalanya. Sedangkan satu peserta berikutnya terlambat mengirimkan karya nawalanya sehingga tim penulis tidak dapat membantu menggandakan hard copy dari nawala yang telah dibuat. 
Berikut adalah halaman depan dari nawala yang merupakan hasil praktik dari para peserta pengabdian masyarakat ini.

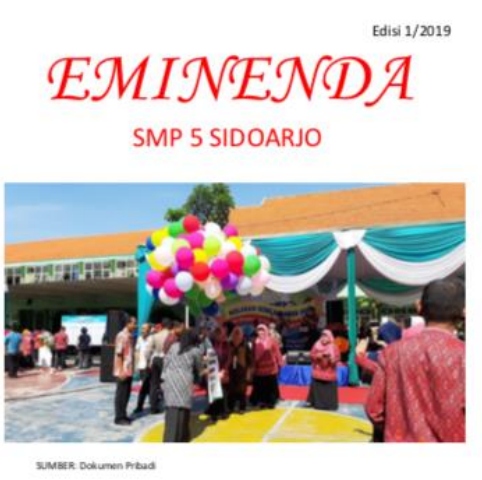

Warga Spenmada

siap Mendukung Sekolah Ramah Anak

Gambar 1. Karya Peserta dari SMP Negeri 5 Sidoarjo

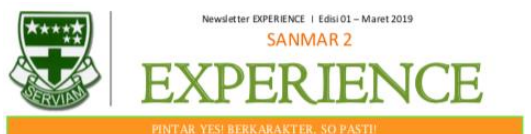

INDIRA MENANG LAGI, YEAH!
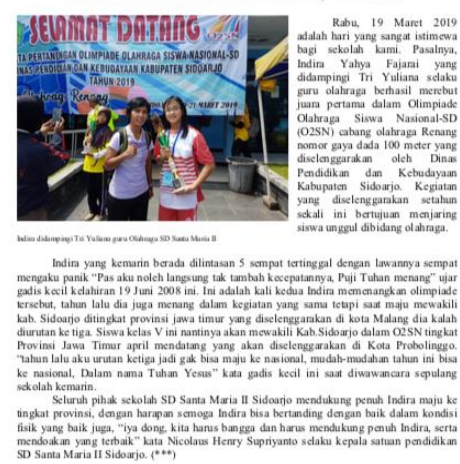

Gambar 2. Karya Peserta dari SD Santa Maria Sidoarjo

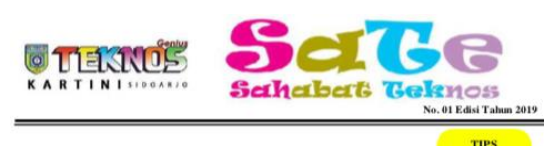

Thes
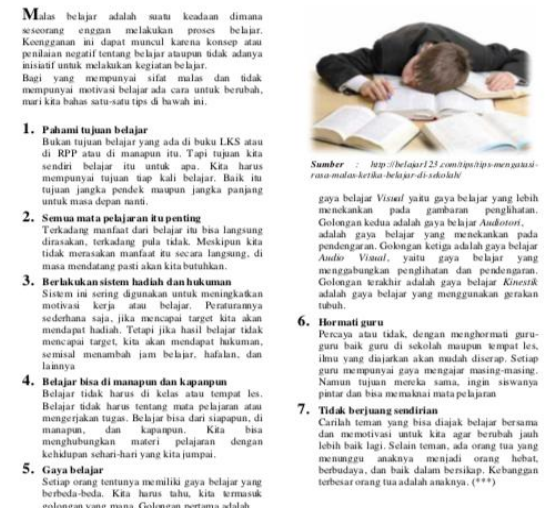

Gambar 3. Karya Peserta dari BimBel TEKNOS Sidoarjo
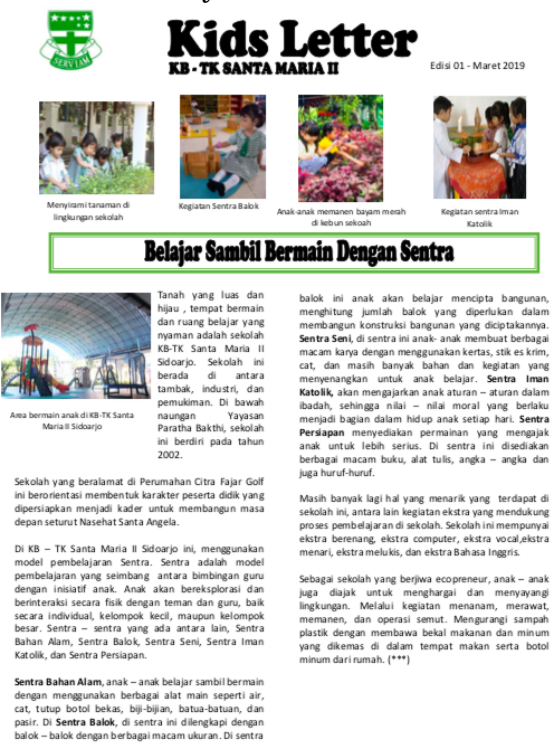

Gambar 4. Karya peserta dari KB/ TK Santa Maria Sidoarjo

\section{BESTARI}

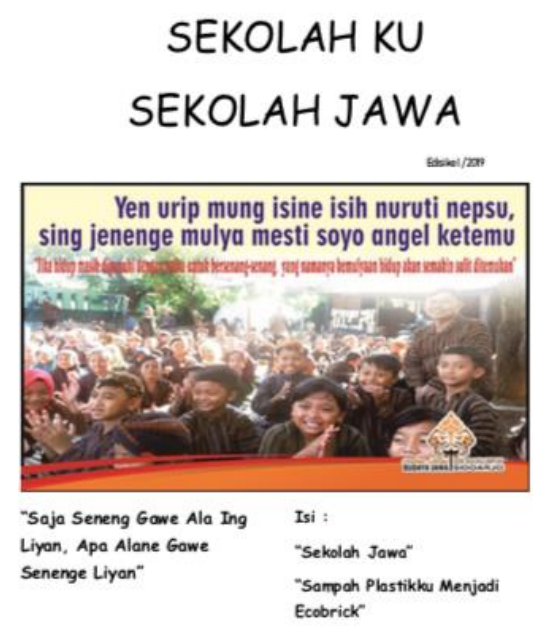

Gambar 5. Karya peserta dari SD Sidoklumpuk Sidoarjo 
UPDATES

SIMP SANIMAR II

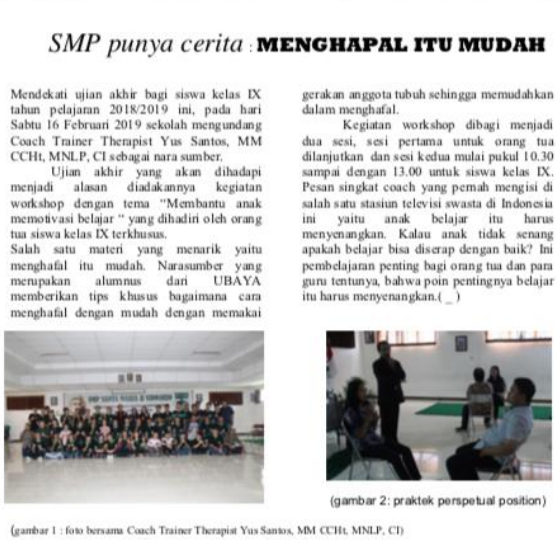

Gambar 6. Karya peserta dari SMP Santa Maria II Sidoarjo

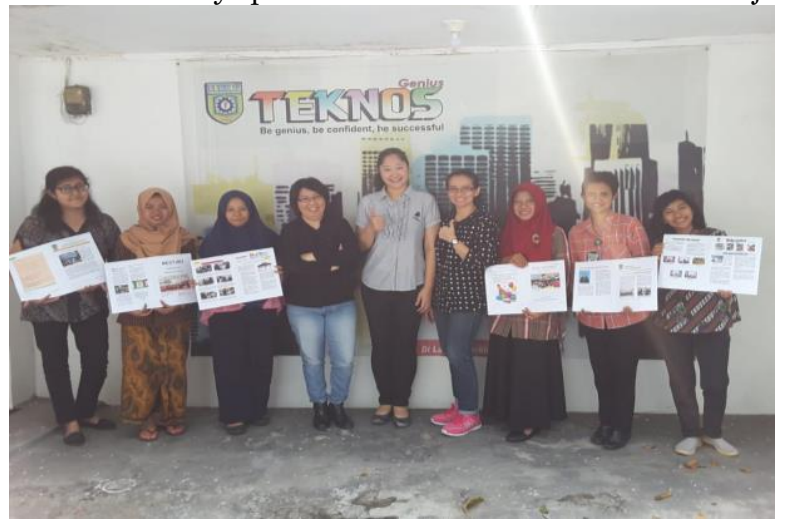

Gambar 7. Foto bersama peserta dengan karya masingmasing

\section{Kendala dan Solusi}

Dalam pelaksanaan pengabdian masyarakat ini tidak ada kendala yang mengganggu proses, baik selama pembagian materi maupun praktik menulis serta praktik membuat desain. Namun, beberapa peserta hanya hadir beberapa kali karena terkendala dengan pekerjaan di sekolah. Meski demikian, proses pendampingan tetap berjalan dengan lancar. Kesulitan peserta dalam hal penulisan maupun dalam pembuatan desain dapat terjawab dengan melakukan praktik langsung.

Sebagai solusi, tim penulis tetap memberikan materi dalam bentuk hard copy kepada peserta agar dapat mempelajari lebih lanjut perihal kebutuhan adanya nawala dalam institusi pendidikan tempat mereka berkontribusi.

\section{SIMPULAN DAN REKOMENDASI}

Proses pendampingan yang dilakukan oleh tim penulis pada mitra abdimas dijalankan dengan konsisten sejak dari pembagian materi hingga pengerjaan nawala, yang dimulai dari menulis naskah (berita) hingga pembuatan desain seder- hana. Nawala yang dihasilkan oleh masing-masing peserta terdiri dari 4 (halaman) dengan konten berita seputar kegiatan sekolah selama masa pendampingan berlangsung.

Abdimas ini terlaksana dengan tujuan memberikan ketrampilan tambahan bagi para guru, khususnya dalam hal membagikan informasi seputar kegiatan sekolah pada publik internal yakni

orang tua siswa maupun informasi yang juga ditujukan pada masyarakat dan pemerintah daerah sebagai publik eksternal. Dengan demikian, abdimas ini telah memenuhi tujuan dari pelaksanaan abdimas karena peserta telah memahami tujuan dari pembuatan nawala, dan peserta juga telah membuat nawala baik dalam hal penulisan konten maupun dalam pembuatan desain.

Sebagai rekomendasi, abdimas dapat dilakukan di kampus yang memiliki fasilitas untuk pengerjaan naskah nawala, teristimewa dalam hal pelatihan pembuatan desain nawala. Bagaimana pun, saat ini pembuatan desain-termasuk desain nawala-memerlukan fasilitas komputer dengan spesifikasi yang memadai.

\section{UCAPAN TERIMAKASIH}

Haturan terima kasih kepada Ibu Anita Nusantari yang telah menjadi jembatan bagi penulis dalam membagikan pengetahuan serta pengalaman dalam pembuatan Nawala, khususnya bagi tenaga pendidik di kota Sidoarjo.

\section{DAFTAR PUSTAKA}

Ali, Dini Salmiyah Fithrar. 2017. Marketing Public Relations - Diantara Penjualan dan Pencitraaan. Yogyakarta: DeePublish.

Bahri, A. Saeful. 2020. Manajemen Humas pada Lembaga Pendidikan. Bandung: Widina Bhakti Persada.

Hikmat, Mahi. M. 2018. Jurnalistik Literary Journalism. Jakarta: Kencana.

Kriyantono, Rachmat. 2014. Teori-teori Public Relations Perspektif Barat dan Lokal: Aplikasi Penelitian dan Praktik. Jakarta: Kencana.

Lesmana, Fanny. 2017. Feature Tulisan Jurnalistik yang Kreatif. Yogyakarta: Penerbit ANDI.

Morissan. 2014. Manajemen Public Relations. Jakarta: Kencana. 
Rustan, Suriyanto. 2020. LayOut 2020 Buku 1. Jakarta: nulisbuku.com.

Sopian. 2016. Public Relations Writing. Konsep, teori, praktik. Jakarta: Grasindo.

Supadiyanto. 2020. Pengantar Jurnalisme Konvergentif Menjawab Tren Industri Media Digital. Yogyakarta: Pustaka Baru. 